\title{
FUTURE INSECURE: Women, Feminism and the Third Term
}

During the wake following 11 June, amidst the general funereal gloom about the progressive future of Britain, we asked a number of women to write short pieces on their particular areas of concern in the hope of initiating discussion of prospects and possibilities for women and for feminism in the late 80 s and 90 s. As Loretta Loach says in her article we were moved by a 'desire to intervene in ways that are practical and creative rather than denunciatory and defeatist'. Included are takes on women and social security, the public sector, the NHS, sex education, gender, race and the Labour Party and the future of socialist feminism in the new political conjuncture. We asked for more contributions than could be produced in the time available. We hope in future issues to add similar pieces on employment outside the public sector, education, the arts, local government, law, the environment, the city and defence. 